\title{
Transcranial Magnetic Stimulation in Alzheimer's Disease: Are We Ready?
}

\author{
Marina Weiler, Kevin C. Stieger, Jeffrey M. Long, and ${ }^{D}$ Peter R. Rapp
}

https://doi.org/10.1523/ENEURO.0235-19.2019

Neurocognitive Aging Section, Laboratory of Behavioral Neuroscience, National Institute on Aging, Intramural Research Program, Baltimore, Maryland 21224

\begin{abstract}
Transcranial magnetic stimulation (TMS) is among a growing family of noninvasive brain stimulation techniques being developed to treat multiple neurocognitive disorders, including Alzheimer's disease (AD). Although small clinical trials in AD have reported positive effects on cognitive outcome measures, significant knowledge gaps remain, and little attention has been directed at examining the potential influence of TMS on AD pathogenesis. Our review briefly outlines some of the proposed neurobiological mechanisms of TMS benefits in AD, with particular emphasis on the modulatory effects on excitatory/inhibitory balance. On the basis of converging evidence from multiple fields, we caution that TMS therapeutic protocols established in young adults may have unexpected detrimental effects in older individuals or in the brain compromised by AD pathology. Our review surveys clinical studies of TMS in AD alongside basic research as a guide for moving this important area of work forward toward effective treatment development.
\end{abstract}

Key words: brain stimulation; excitatory/inhibitory balance; therapeutic development

\section{Significance Statement}

There is an urgent need for the development of new, effective strategies in the battle against Alzheimer's disease (AD). Transcranial magnetic stimulation (TMS) has emerged as a promising possibility, but evidence regarding long-term efficacy and mechanism of action is limited. Among the major unresolved issues, findings linking the effects of TMS on excitatory/inhibitory balance with mechanisms of AD pathogenesis merit careful consideration. Our survey of clinical TMS studies in AD alongside basic research aims to move the area forward toward effective treatment development using noninvasive brain stimulation.

\section{The need for novel approaches to AD treatment}

Alzheimer's disease (AD), the most common form of dementia, is characterized by progressive memory im-

\footnotetext{
Received June 18, 2019; accepted December 11, 2019; First published December 17, 2019.

The authors declare no competing financial interests.

Author contributions: M.W., K.C.S., J.M.L. and P.R.R. conceived the concepts in this review and wrote the paper.

This work was supported entirely by the Intramural Research Program of the National Institute on Aging, National Institutes of Health.

Acknowledgments: We thank the members of the Neurocognitive Aging Section, and Drs. Kevin G. Becker, Luigi Ferrucci, Susan Resnick, and Madhav Thambisetty for input on an earlier version of this commentary.

Correspondence should be addressed to Marina Weiler at weiler_marina@yahoo.com.br or Peter Rapp at rappp@mail.nih.gov.
}

pairment and associated decline in multiple cognitive domains, ultimately leaving patients incapacitated. Inexorably eroding the lifetime of memories that defines us, AD robs patients of their unique identity. The neuropathological hallmarks of $A D$ prominently include microscopic foci of degenerating neurites and extracellular amyloid $\beta$-protein $(A \beta)$ deposition, together with intracellular aggregates of hyperphosphorylated tau protein that disrupt microtubule organization (Selkoe, 2001). The single great-

https://doi.org/10.1523/ENEURO.0235-19.2019

Copyright (C) 2020 Weiler et al.

This is an open-access article distributed under the terms of the Creative Commons Attribution 4.0 International license, which permits unrestricted use, distribution and reproduction in any medium provided that the original work is properly attributed. 
est risk for $A D$ is aging. The $\varepsilon 4$ allele of the apolipoprotein E (APOE) gene is present in $\sim 40 \%$ of cases and is the strongest genetic risk for the sporadic, late-onset form of AD (Farrer et al., 1997; Heffernan et al., 2016). In the absence of effective interventions for disease prevention or slowing, the projected burden of AD represents a looming health-care crisis as the population of most industrialized countries continues to grow older.

Currently approved pharmacological treatments for $A D$ offer limited symptomatic relief for some patients, and none alter the underlying progression of disease. While the search for new drugs with improved clinical efficacy is ongoing, increasing attention is focused on diseasemodifying strategies aimed at bending the trajectory of aging toward healthy neurocognitive outcomes. Ideally, intervention would be initiated in at-risk individuals before the clinical expression of disease, during the decadeslong prodromal phase thought to precede AD diagnosis. Noninvasive brain stimulation (NIBS) has generated considerable interest in this context. Prominently including transcranial magnetic stimulation (TMS) and transcranial direct current stimulation, this family of related technologies shares a generally well tolerated safety profile in healthy young adults and is currently under investigation for treating a growing list of potential indications (Rossi et al., 2009; Guo et al., 2017).

Among the various types of NIBS, TMS has received the greatest attention in clinical research on neuropsychiatric disorders. The mechanistic basis of TMS benefits is poorly understood, but there is general agreement that cortical excitability can be persistently modified by the repetitive delivery of a high-intensity magnetic field, generated by passing electrical current through an inductive coil. Repetitive TMS (rTMS), delivered in daily hour-long sessions over the course of several weeks was approved by the US Food and Drug Administration (FDA) for the treatment of pharmacologically refractory depression in 2008. In general, trials of rTMS treatment versus sham showed significant improvement in depression scores and lower rates of remission with rTMS (Health Quality Ontario, 2016; Pohar and Farrah, 2019), benefits that can be enhanced when rTMS is combined with antidepressant medication (Wei et al., 2017). In the ensuing years, the range of potential clinical applications under investigation has increased dramatically, including a number of relatively small trials in AD (Table 1).

\section{Therapeutic effects of rTMS in AD}

Developing NIBS as a potential intervention for any clinical indication critically involves the choice of an appropriate stimulation protocol. Generally, rTMS protocols are operationally classified as "low frequency" or "high frequency," and "conventional" or "patterned." Lowfrequency typically refers to stimulation rates $\leq 1 \mathrm{~Hz}$, whereas rates $\geq 3 \mathrm{~Hz}$ are considered high frequency (including the 10 and $20 \mathrm{~Hz}$ frequencies most commonly used in AD trials). In conventional protocols, single TMS pulses are applied in a regular rhythm; in patterned rTMS, short, high-frequency bursts are interleaved with brief periods of no stimulation. Some examples of patterned
rTMS include stimulation mimicking theta activity, wherein short bursts of high-frequency pulses repeated at $5 \mathrm{~Hz}$ [theta burst stimulation (TBS)] are delivered as continuous TBS or intermittent TBS (iTBS) pulses. Perhaps most important with respect to the clinical effects of stimulation, low-frequency rTMS protocols are understood to result in cortical suppression and inhibition, whereas highfrequency stimulation increases cortical facilitation and excitability (Huang et al., 2005). Beyond stimulation frequency, a wide variety of generally untested factors are likely to influence the outcome of rTMS, including coil shape, coil-cortex distance, motor threshold normalization, area of stimulation, use of concomitant medication, and machine output, among others (Lang et al., 2006; Kar, 2019).

Initial studies of rTMS effects in AD focused on highfrequency protocols almost exclusively (Table 1, procedural details of available rTMS trials). For example, in research examining language function, mild and moderate $A D$ participants received $20 \mathrm{~Hz}$ unilateral TMS over the dorsolateral prefrontal cortex (dIPFC; Cotelli et al., 2006, 2008). Object naming ability improved during stimulation, and the endurance of these effects, immediately after and 8 weeks following treatment, was assessed in subsequent work (Cotelli et al., 2011). The duration of intervention was also manipulated, with one group receiving a 4 week course of rTMS, while a second underwent 2 weeks of sham treatment followed by 2 weeks of rTMS. Auditory sentence comprehension improved in both groups, and although the previously reported effect on naming was not confirmed, comprehension benefits persisted for 8 weeks. Other outcome measures were unaffected, including activities of daily living and global cognition. In a more recent study, episodic memory improved in comparison with pretreatment scores in AD patients who received 20 $\mathrm{Hz}$ stimulation over the precuneus, whereas no difference was detected after sham stimulation (Koch et al., 2018). A related investigation tested $10 \mathrm{~Hz}$ dIPFC stimulation in a mild cognitive impairment ( $\mathrm{MCl}$ ) sample (Drumond Marra et al., 2015) and reported significant benefit relative to sham on tests of everyday memory, with effects persisting up to 1 month. However, in this case, sham group scores for logical memory, executive function, and language also varied over the observation period. Improvements in performance when assessment is repeated over time, or "practice effects," although controllable with appropriate experimental design, are a frequent confound and complicate interpretation in this area of research. Generally similar results have been reported in other small trials (Eliasova et al., 2014; Rutherford et al., 2015; Zhao et al., 2017), as detailed in Table 1.

Studies directly comparing cognitive outcomes following high-frequency versus low-frequency stimulation in patients with AD were first reported in 2012. In one investigation, 20 or $1 \mathrm{~Hz}$ rTMS was delivered bilaterally over the dIPFC in participants with mild or severe dementia (Ahmed et al., 2012). High-frequency stimulation in the mild dementia group was more effective than $1 \mathrm{~Hz}$ relative to pretreatment scores as measured by all clinical assessments [i.e., the Mini-Mental State Examination (MMSE), 
Table 1: Summary characteristics of clinical studies using rTMS to treat AD

\begin{tabular}{|c|c|c|c|c|c|c|c|c|}
\hline Authors & Sample & $\begin{array}{l}\text { Exclusion/ } \\
\text { inclusion } \\
\text { criteria }\end{array}$ & Methods & Stimulation site & $\begin{array}{l}\text { Cognitive } \\
\text { outcome } \\
\text { variable }\end{array}$ & $\begin{array}{l}\text { Assessment } \\
\text { schedule }\end{array}$ & $\begin{array}{l}\text { Summary } \\
\text { results }\end{array}$ & $\begin{array}{c}\text { Author } \\
\text { conclusions }\end{array}$ \\
\hline $\begin{array}{l}\text { Cotelli et al., } \\
2006\end{array}$ & $\begin{array}{l}15 \text { mild to } \\
\text { moderate AD } \\
\text { patients }\end{array}$ & $\begin{array}{l}\text { Exclusion of patients } \\
\text { with major } \\
\text { depression }\end{array}$ & $\begin{array}{l}\text { One session of } 20 \\
\mathrm{~Hz} \text { rTMS during } \\
\text { cognitive } \\
\text { stimulation. No } \\
\text { sham group }\end{array}$ & $\begin{array}{l}\text { Unilateral dIPFC } \\
\text { and sham } \\
\text { region }\end{array}$ & $\begin{array}{l}\text { Action naming } \\
\text { and Object } \\
\text { naming }\end{array}$ & $\begin{array}{l}\text { Baseline and during } \\
\text { stimulation }\end{array}$ & $\begin{array}{l}\text { Patients improved } \\
\text { action naming } \\
\text { accuracy during } \\
\text { stimulation with rTMS } \\
\text { applied to either the } \\
\text { right or left dIPFC. }\end{array}$ & $\begin{array}{l}\text { High-frequency } \\
\text { TMS could } \\
\text { represent a } \\
\text { potential } \\
\text { treatment for } \\
\text { language deficits } \\
\text { in } A D \text { patients. }\end{array}$ \\
\hline $\begin{array}{l}\text { Cotelli et al., } \\
2008\end{array}$ & $\begin{array}{l}12 \text { mild } A D, 12 \\
\text { moderate to } \\
\text { severe } A D \\
\text { patients }\end{array}$ & $\begin{array}{l}\text { Exclusion of patients } \\
\text { with major } \\
\text { depression }\end{array}$ & $\begin{array}{l}\text { One session of } 20 \\
\mathrm{~Hz} \text { rTMS during } \\
\text { cognitive stimulus. } \\
\text { No sham group }\end{array}$ & $\begin{array}{l}\text { Unilateral dIPFC } \\
\text { and sham } \\
\text { region }\end{array}$ & $\begin{array}{l}\text { Action naming } \\
\text { and Object } \\
\text { naming }\end{array}$ & $\begin{array}{l}\text { Baseline and during } \\
\text { stimulation }\end{array}$ & $\begin{array}{l}\text { Mild AD improved } \\
\text { action naming } \\
\text { accuracy during } \\
\text { stimulation with rTMS } \\
\text { applied to either the } \\
\text { right or left DLPFC. } \\
\text { Moderate to severe } \\
\text { AD improved action } \\
\text { and object naming } \\
\text { accuracy with rTMS } \\
\text { applied to either the } \\
\text { right or left DLPFC. }\end{array}$ & $\begin{array}{l}\text { High-frequency } \\
\text { TMS could } \\
\text { represent a } \\
\text { potential } \\
\text { treatment for } \\
\text { language deficits } \\
\text { not only in the } \\
\text { early phase of } \\
\text { AD, but also in } \\
\text { more advanced } \\
\text { stages. }\end{array}$ \\
\hline $\begin{array}{l}\text { Cotelli et al., } \\
2011\end{array}$ & $\begin{array}{l}10 \text { moderate } A D \\
\text { patients }\end{array}$ & $\begin{array}{l}\text { Exclusion of patients } \\
\text { with major } \\
\text { depression }\end{array}$ & $\begin{array}{l}\text { Two groups: a } 4 \\
\text { week stimulation } \\
\text { group, and } 2 \\
\text { week placebo } \\
\text { treatment }+2 \\
\text { weeks of } \\
\text { stimulation. } 20 \mathrm{~Hz} \\
\text { rTMS, for } 25 \mathrm{~min} / \\
\text { d, } 5 \text { d/week. No } \\
\text { sham group }\end{array}$ & $\begin{array}{l}\text { dIPFC } \\
\text { (hemisphere not } \\
\text { specified) }\end{array}$ & $\begin{array}{l}\text { MMSE, ADL, } \\
\text { IADL, Picture } \\
\text { naming, SC- } \\
\text { BADA, } \\
\text { Aachen } \\
\text { Aphasia Test, } \\
\text { serial curve } \\
\text { position, } \\
\text { Cognitive } \\
\text { estimation test }\end{array}$ & $\begin{array}{l}\text { Baseline, } 2,4 \text {, and } \\
12 \text { weeks after } \\
\text { stimulation onset }\end{array}$ & $\begin{array}{l}\text { The } 4 \text { week } \\
\text { stimulation group } \\
\text { improved on SC- } \\
\text { BADA after the first } 2 \\
\text { weeks of stimulation. } \\
\text { The placebo + real } \\
\text { stimulation group only } \\
\text { improved on SC- } \\
\text { BADA after the } 2 \\
\text { weeks of stimulation. } \\
\text { Effects lasted for } 8 \\
\text { weeks in both groups. }\end{array}$ & $\begin{array}{l}\text { High-frequency } \\
\text { TMS has long } \\
\text { lasting effects on } \\
\text { auditory sentence } \\
\text { comprehension } \\
\text { performance in } \\
\text { moderate AD } \\
\text { patients. }\end{array}$ \\
\hline $\begin{array}{l}\text { Drumond Marra } \\
\text { et al., } 2015\end{array}$ & $34 \mathrm{MCl}$ subjects & $\begin{array}{l}\text { Exclusion of patients } \\
\text { with psychiatric } \\
\text { disorders }\end{array}$ & $\begin{array}{l}\text { Sham and } \\
\text { stimulation } \\
\text { groups. } 10 \mathrm{~Hz} \text { for } \\
5 \mathrm{~s}, 25 \mathrm{~s} \text { intertrain } \\
\text { interval } 20 \mathrm{~min} / \mathrm{d} \\
\text { for } 5 \mathrm{~d} / \text { week for } 2 \\
\text { weeks }\end{array}$ & Left dIPFC & $\begin{array}{l}\text { IQCODE, B- } \\
\text { ADL, MMSE, } \\
\text { RBMT, Logical } \\
\text { memory I and } \\
\text { II, RAVLT, } \\
\text { Letter-number } \\
\text { sequencing } \\
\text { test, Digit } \\
\text { span, TMT } \\
\text { A/B, Verbal } \\
\text { fluency tests, } \\
\text { Victoria } \\
\text { Stroop Test }\end{array}$ & $\begin{array}{l}\text { Baseline, end of } \\
\text { treatment and } 30 \\
\text { days after end of } \\
\text { treatment }\end{array}$ & $\begin{array}{l}\mathrm{MCl} \text { improved RBMT } \\
\text { scores after } 10 \mathrm{~Hz} \\
\text { stimulation, lasting up } \\
\text { for } 30 \mathrm{~d} \text {. MCI } \\
\text { improved TMT-B } 30 \mathrm{~d} \\
\text { after treatment. Sham } \\
\text { improved Logical } \\
\text { memory, letter-number } \\
\text { sequencing and TMT- } \\
\mathrm{B} \text { after treatment. } \\
\text { Effects on the Logical } \\
\text { memory lasted up for } \\
30 \text { d. Sham improved } \\
\text { verbal fluency } 30 \mathrm{~d} \\
\text { after treatment. }\end{array}$ & $\begin{array}{l}\text { High-frequency } \\
\text { rTMS may } \\
\text { represent an } \\
\text { effective } \\
\text { intervention for } \\
\mathrm{MCl} \text { and could } \\
\text { delay further } \\
\text { decline. }\end{array}$ \\
\hline $\begin{array}{l}\text { Bentwich et al., } \\
2011\end{array}$ & $\begin{array}{l}7 \text { mild or } \\
\text { moderate AD } \\
\text { patients }\end{array}$ & $\begin{array}{l}\text { Inclusion of } 2 \\
\text { patients with } \\
\text { depression and } 4 \\
\text { patients with } \\
\text { depression in } \\
\text { remission }\end{array}$ & $\begin{array}{l}\text { No sham groups. } \\
\text { rTMS-COG. } \\
\text { Intensive }+ \\
\text { maintenance } \\
\text { phase ( } 4.5 \\
\text { months of } \\
\text { stimulation total). } \\
10 \mathrm{~Hz} \text { for } 2 \mathrm{~s}, 20 \\
\text { trains }\end{array}$ & $\begin{array}{l}\text { Broca, right/left } \\
\text { dIPFC, } \\
\text { Wernicke, right/ } \\
\text { left pSAC }\end{array}$ & $\begin{array}{l}\text { ADAS-cog, } \\
\text { CGIC, MMSE, } \\
\text { ADAS-ADL, } \\
\text { HAMILTON, } \\
\text { NPI }\end{array}$ & $\begin{array}{l}\text { Baseline, after } \\
\text { intensive phase, } \\
\text { and after } \\
\text { maintenance phase }\end{array}$ & $\begin{array}{l}\text { Improved ADAS-cog } \\
\text { scores after } 6 \text { weeks } \\
\text { and } 4.5 \text { months of } \\
\text { treatment. No } \\
\text { significant changes on } \\
\text { other tests. }\end{array}$ & $\begin{array}{l}\text { High-frequency } \\
\text { TMS combined } \\
\text { with cognitive } \\
\text { training may have } \\
\text { a synergistic } \\
\text { effect and } \\
\text { improve cognition } \\
\text { for up to } 4.5 \\
\text { months. }\end{array}$ \\
\hline $\begin{array}{l}\text { Ahmed et al., } \\
2012\end{array}$ & $\begin{array}{l}32 \text { mild to } \\
\text { moderate } A D, \\
13 \text { severe } A D \\
\text { patients }\end{array}$ & $\mathrm{N} / \mathrm{A}$ & $\begin{array}{l}\text { Sham, } 20 \mathrm{~Hz} \text { and } \\
1 \mathrm{~Hz} \text { groups. } 20 \\
\mathrm{~Hz}: 5 \mathrm{~s}, 20 \text { trains. } \\
1 \mathrm{~Hz}: 2 \text { trains of } \\
1000 \mathrm{~s}, 30 \mathrm{~s} \\
\text { intertrain interval. } \\
5 \mathrm{~d}\end{array}$ & (Continued) & $\begin{array}{l}\text { MMSE, IADL, } \\
\text { GDS }\end{array}$ & $\begin{array}{l}\text { Baseline, end of } \\
\text { treatment, } 1 \text { and } 3 \\
\text { months after } \\
\text { treatment }\end{array}$ & $\begin{array}{l}\text { Mild to moderate } \mathrm{AD} \\
\text { improved in all tests } \\
\text { after } 20 \mathrm{~Hz} \text { up to } 3 \\
\text { months compared to } 1 \\
\mathrm{~Hz} \text { and sham. Mild to } \\
\text { moderate } \mathrm{AD} \\
\text { improved in IADL after } \\
1 \mathrm{~Hz} \text { compared to } \\
\text { sham. There was no } \\
\text { improvement in severe } \\
\mathrm{AD} \text {. }\end{array}$ & $\begin{array}{l}\text { High-frequency } \\
\text { TMS has long } \\
\text { lasting effects in } \\
\text { mild to moderate } \\
\text { AD and is more } \\
\text { effective than } \\
\text { low-frequency } \\
\text { stimulation. }\end{array}$ \\
\hline
\end{tabular}


Table 1: Continued

\begin{tabular}{|c|c|c|c|c|c|c|c|c|}
\hline Authors & Sample & $\begin{array}{l}\text { Exclusion/ } \\
\text { inclusion } \\
\text { criteria }\end{array}$ & Methods & Stimulation site & $\begin{array}{l}\text { Cognitive } \\
\text { outcome } \\
\text { variable }\end{array}$ & $\begin{array}{l}\text { Assessment } \\
\text { schedule }\end{array}$ & $\begin{array}{l}\text { Summary } \\
\text { results }\end{array}$ & $\begin{array}{c}\text { Author } \\
\text { conclusions }\end{array}$ \\
\hline $\begin{array}{l}\text { Turriziani et al., } \\
2012\end{array}$ & $\begin{array}{l}100 \text { healthy } \\
\text { control subjects, } \\
8 \mathrm{MCl} \text { subjects }\end{array}$ & $\begin{array}{l}\text { Exclusion of } \mathrm{MCl} \\
\text { subjects with history } \\
\text { of psychiatric } \\
\text { disorders }\end{array}$ & $\begin{array}{l}\text { Sham and } \\
\text { stimulation } \\
\text { groups. One } \\
\text { session of } 1 \mathrm{~Hz} \\
\text { and iTBS applied } \\
\text { in controls, } 1 \mathrm{~Hz} \\
\text { applied in } \mathrm{MCl} \text {. } \\
\text { iTBS: } 20 \mathrm{trains} \text {, } \\
\text { three } 50 \mathrm{~Hz} \\
\text { pulses (a burst) } \\
\text { repeated at } 5 \mathrm{~Hz} \\
\text { for } 2 \mathrm{~s} .1 \mathrm{~Hz}: 600 \\
\text { pulses }\end{array}$ & $\begin{array}{l}\text { Unilateral dIPFC } \\
\text { for healthy } \\
\text { controls and } \\
\text { bilateral dIPFC } \\
\text { for } \mathrm{MCl} \text { (interval } \\
\text { of } 3 \text { weeks) }\end{array}$ & $\begin{array}{l}\text { Recognition } \\
\text { memory for } \\
\text { faces, } \\
\text { buildings and } \\
\text { words. }\end{array}$ & $\begin{array}{l}\text { Immediately after } \\
\text { stimulation }\end{array}$ & $\begin{array}{l}\text { Recognition memory } \\
\text { improved in controls } \\
\text { and } \mathrm{MCl} \text { after } 1 \mathrm{~Hz} \\
\text { stimulation over the } \\
\text { right dIPFC. iTBS over } \\
\text { right dIPFC impaired } \\
\text { nonverbal recognition } \\
\text { memory in healthy } \\
\text { controls. iTBS over left } \\
\text { dIPFC had no effect in } \\
\text { healthy controls. }\end{array}$ & $\begin{array}{l}\text { Low frequency } \\
\text { TMS over the } \\
\text { right dIPFC } \\
\text { improves } \\
\text { recognition } \\
\text { memory when } \\
\text { applied during } \\
\text { encoding in } \mathrm{MCl} \\
\text { and healthy } \\
\text { controls. }\end{array}$ \\
\hline $\begin{array}{l}\text { Rabey et al., } \\
2013\end{array}$ & $\begin{array}{l}15 \text { mild to } \\
\text { moderate } A D \\
\text { patients }\end{array}$ & $\mathrm{N} / \mathrm{A}$ & $\begin{array}{l}\text { Sham and } \\
\text { stimulation } \\
\text { groups. rTMS- } \\
\text { COG. Intensive } \\
\text { phase + } \\
\text { maintenance } \\
\text { phase ( } 4.5 \\
\text { months in total). } \\
10 \mathrm{~Hz}, 20 \text { trains, } \\
\text { for } 2 \mathrm{~s} \text {. }\end{array}$ & $\begin{array}{l}\text { Broca, right/left } \\
\text { dIPFC, } \\
\text { Wernicke, right/ } \\
\text { left pSAC }\end{array}$ & $\begin{array}{l}\text { ADAS-cog, } \\
\text { CGIC, NPI }\end{array}$ & $\begin{array}{l}\text { Baseline, after } \\
\text { intensive phase and } \\
\text { after maintenance } \\
\text { phase }\end{array}$ & $\begin{array}{l}\text { AD patients improved } \\
\text { on ADAS-cog and } \\
\text { CGIC scores at the } \\
\text { end of intensive } \\
\text { phase. Effects lasted } \\
\text { up for } 4.5 \text { months. }\end{array}$ & $\begin{array}{l}\text { rTMS-COG } \\
\text { treatment } \\
\text { significantly } \\
\text { improves } \\
\text { cognition, is } \\
\text { superior to } \\
\text { currently available } \\
\text { medications, and } \\
\text { better than COG } \\
\text { or TMS alone. }\end{array}$ \\
\hline $\begin{array}{l}\text { Eliasova et al., } \\
2014\end{array}$ & $\begin{array}{l}3 \mathrm{MCl} \text { and } 7 \\
\text { mild } \mathrm{AD} \text { patients }\end{array}$ & $\mathrm{N} / \mathrm{A}$ & $\begin{array}{l}\text { Sham-controlled } \\
\text { study with a } \\
\text { crossover design. } \\
2 \text { sessions of } 10 \\
\mathrm{~Hz}, 45 \text { trains of } \\
4.9 \text { second } \\
\text { duration with an } \\
\text { interval of } 25 \mathrm{~s} \text {, } \\
\text { resulting in } 2250 \\
\text { pulses/session. } \\
\text { One-day interval } \\
\text { between each } \\
\text { session }\end{array}$ & $\begin{array}{l}\text { Right inferior } \\
\text { frontal gyrus } \\
\text { and right } \\
\text { superior } \\
\text { temporal gyrus } \\
\text { (active rTMS), } \\
\text { and vertex } \\
\text { (sham rTMS) }\end{array}$ & $\begin{array}{l}\text { TMT, Stroop } \\
\text { test, complex } \\
\text { visual scene } \\
\text { encoding task } \\
\text { test }\end{array}$ & $\begin{array}{l}\text { Baseline and } \\
\text { immediately after } \\
\text { each stimulation }\end{array}$ & $\begin{array}{l}\text { Stimulation over the } \\
\text { inferior frontal gyrus } \\
\text { induced significant } \\
\text { improvement in the } \\
\text { TMT A and B. No } \\
\text { significant difference } \\
\text { in the Stroop test or in } \\
\text { the CVSET after the } \\
\text { rTMS of the right } \\
\text { inferior frontal gyrus. }\end{array}$ & $\begin{array}{l}\text { Modulating the } \\
\text { inferior frontal } \\
\text { gyrus excitability } \\
\text { with rTMS may } \\
\text { lead to clinically } \\
\text { relevant } \\
\text { improvement in } \\
\text { attentional task } \\
\text { performance in } \\
\text { early AD patients. }\end{array}$ \\
\hline $\begin{array}{l}\text { Rutherford } \\
\text { et al., } 2015\end{array}$ & $\begin{array}{l}\text { Stage 1: } 10 \text { mild } \\
\text { to moderate } A D \\
\text { patients; } \\
\text { Stage 2: } 6 \text { mild } \\
\text { to moderate } A D \\
\text { patients }\end{array}$ & $\begin{array}{l}\text { Exclusion of patients } \\
\text { with moderate or } \\
\text { severe depression. } \\
\text { Inclusion of one } \\
\text { patient with mild } \\
\text { depression }\end{array}$ & $\begin{array}{l}4 \text { week block of } \\
\text { double-blind } \\
\text { treatment with } \\
\text { sham condition } \\
\text { (Stage } 1 \text { ) followed } \\
\text { by } 2 \text { weeks of } \\
\text { open-label } \\
\text { maintenance } \\
\text { treatment } \\
\text { repeated every } 3 \\
\text { months (Stage } 2 \text { ). } \\
20 \text { Hz ( } 40 \text { pulses } \\
\text { per burst) with } \\
5 \text {-second inter- } \\
\text { train intervals } \\
\text { during cognitive } \\
\text { task. } 2000 \text { pulses } \\
\text { to each side }\end{array}$ & $\begin{array}{l}\text { Both the left } \\
\text { and right } \\
\text { DLPFC per } \\
\text { session }\end{array}$ & $\begin{array}{l}\text { ADAS-cog, } \\
\text { RMBC, MoCA }\end{array}$ & $\begin{array}{l}\text { Stage 1: baseline } \\
\text { and } 4 \text { weeks after } \\
\text { the treatment. } \\
\text { Stage 2: a few days } \\
\text { after the treatment. } \\
\text { MoCA was } \\
\text { assessed every } \\
\text { week in both stages }\end{array}$ & $\begin{array}{l}\text { Stage 1: no } \\
\text { statistically significant } \\
\text { changes on ADAS-cog } \\
\text { or RMBC scores } \\
\text { comparing treated vs } \\
\text { sham. Treated } \\
\text { patients scored higher } \\
\text { on MoCA in } 2 \text { and } 3 \\
\text { weeks after start of } \\
\text { treatment compared } \\
\text { to baseline. Stage 2: } \\
\text { with the exception of } \\
\text { the ADAS-cog scores } \\
\text { for } 2 \text { patients, all } \\
\text { decline rates were } \\
\text { better than the } \\
\text { expected. }\end{array}$ & $\begin{array}{l}\text { rTMS can be an } \\
\text { effective tool for } \\
\text { improving the } \\
\text { cognitive abilities } \\
\text { of patients with } \\
\text { early to moderate } \\
\text { stages of AD. } \\
\text { However, the } \\
\text { positive effects of } \\
\text { rTMS may persist } \\
\text { for only up to a } \\
\text { few weeks. } \\
\text { Specific skills } \\
\text { being practiced } \\
\text { during rTMS } \\
\text { treatment may } \\
\text { retain their } \\
\text { improvement for } \\
\text { longer periods. }\end{array}$ \\
\hline $\begin{array}{l}\text { Rabey and } \\
\text { Dobronevsky, } \\
2016\end{array}$ & $\begin{array}{l}30 \text { mild to } \\
\text { moderate } A D \\
\text { patients }\end{array}$ & $\mathrm{N} / \mathrm{A}$ & $\begin{array}{l}\text { No sham groups. } \\
\text { rTMS-COG. } \\
\text { Intensive phase } \\
\text { only ( } 6 \text { weeks). } 10 \\
\mathrm{~Hz}, 20 \text { trains for } \\
2 \mathrm{~s}\end{array}$ & $\begin{array}{l}\text { Broca, right/left } \\
\text { dIPFC, } \\
\text { Wernicke, right/ } \\
\text { left pSAC }\end{array}$ & $\begin{array}{l}\text { ADAS-cog, } \\
\text { MMSE }\end{array}$ & $\begin{array}{l}\text { Baseline and end of } \\
\text { treatment }\end{array}$ & $\begin{array}{l}\text { AD patients improved } \\
\text { on ADAS-cog and } \\
\text { MMSE scores at the } \\
\text { end of treatment. }\end{array}$ & $\begin{array}{l}\text { Repeated rTMS- } \\
\text { COG treatment } \\
\text { might be used to } \\
\text { improve patients' } \\
\text { cognitive status } \\
\text { and maintain } \\
\text { improvement over } \\
\text { time. }\end{array}$ \\
\hline
\end{tabular}


Table 1: Continued

\begin{tabular}{|c|c|c|c|c|c|c|c|c|}
\hline Authors & Sample & $\begin{array}{l}\text { Exclusion/ } \\
\text { inclusion } \\
\text { criteria }\end{array}$ & Methods & Stimulation site & $\begin{array}{l}\text { Cognitive } \\
\text { outcome } \\
\text { variable }\end{array}$ & $\begin{array}{l}\text { Assessment } \\
\text { schedule }\end{array}$ & $\begin{array}{l}\text { Summary } \\
\text { results }\end{array}$ & $\begin{array}{c}\text { Author } \\
\text { conclusions }\end{array}$ \\
\hline Lee et al., 2016 & $\begin{array}{l}19 \text { mild } A D, 7 \\
\text { moderate } A D \\
\text { patients }\end{array}$ & $\begin{array}{l}\text { Exclusion of patients } \\
\text { who had taken } \\
\text { psychoactive } \\
\text { medications within a } \\
\text { month of the study }\end{array}$ & $\begin{array}{l}\text { Sham and } \\
\text { stimulation } \\
\text { groups. rTMS- } \\
\text { COG. Intensive } \\
\text { phase (6 weeks). } \\
10 \mathrm{~Hz}, 20 \text { trains } \\
\text { for } 2 \mathrm{~s}\end{array}$ & $\begin{array}{l}\text { Broca, right/left } \\
\text { dIPFC, } \\
\text { Wernicke, right/ } \\
\text { left pSAC }\end{array}$ & $\begin{array}{l}\text { ADAS-cog, } \\
\text { CGIC, MMSE, } \\
\text { GDS }\end{array}$ & $\begin{array}{l}\text { Baseline, end of } \\
\text { treatment and } 6 \\
\text { weeks after end of } \\
\text { treatment }\end{array}$ & $\begin{array}{l}\text { Mild AD patients } \\
\text { improved in ADAS-cog } \\
\text { after treatment and } \\
\text { remained for } 6 \text { weeks, } \\
\text { but no different than } \\
\text { the sham group. The } \\
\text { mild AD group also } \\
\text { improved in MMSE } 6 \\
\text { weeks after end of } \\
\text { treatment. Sham } \\
\text { group improved in } \\
\text { GDS scores at the end } \\
\text { of the treatment. }\end{array}$ & $\begin{array}{l}\text { rTMS-COG is a } \\
\text { useful adjuvant } \\
\text { therapy with } \\
\text { currently available } \\
\text { medication for } \\
\text { AD, especially } \\
\text { during the mild } \\
\text { stage of the } \\
\text { disease. }\end{array}$ \\
\hline $\begin{array}{l}\text { Nguyen et al., } \\
2017\end{array}$ & $\begin{array}{l}2 \mathrm{MCl}, 1 \text { mild } \\
\mathrm{AD} \text {, and } 4 \\
\text { moderate-to- } \\
\text { severe } \mathrm{AD} \\
\text { patients }\end{array}$ & $\mathrm{N} / \mathrm{A}$ & $\begin{array}{l}\text { No sham group. } \\
\text { rTMS-COG. } \\
\text { Intensive phase + } \\
\text { maintenance } \\
\text { phase ( } 4.5 \\
\text { months in total). } \\
10 \mathrm{~Hz}, 20 \text { trains, } \\
\text { for } 2 \mathrm{~s}\end{array}$ & $\begin{array}{l}\text { Broca, right/left } \\
\text { dIPFC, } \\
\text { Wernicke, right/ } \\
\text { left pSAC }\end{array}$ & $\begin{array}{l}\text { ADAS-cog, } \\
\text { MMSE, } \\
\text { Dubois score, } \\
\text { Frontal } \\
\text { Assessment } \\
\text { battery, } \\
\text { Stroop color } \\
\text { test, } \\
\text { locomotor } \\
\text { score, apathy } \\
\text { score, } \\
\text { caregiver } \\
\text { burden } \\
\text { interview and } \\
\text { dependence } \\
\text { score }\end{array}$ & $\begin{array}{l}\text { Baseline, after } \\
\text { intensive phase and } \\
6 \text { months after end } \\
\text { of treatment }\end{array}$ & $\begin{array}{l}\text { Patients improved on } \\
\text { ADAS-cog, locomotor, } \\
\text { apathy and } \\
\text { dependence scores } \\
\text { after intensive phase. } \\
\text { Scores returned to } \\
\text { baseline } 6 \text { months } \\
\text { after treatment. }\end{array}$ & $\begin{array}{l}\text { AD patients can } \\
\text { benefit from } \\
\text { rTMS-COG in } \\
\text { terms of cognitive } \\
\text { performance, } \\
\text { apathy and } \\
\text { independence. } \\
\text { The duration of } \\
\text { the benefit } \\
\text { suggests that the } \\
\text { repetition of a full } \\
\text { course of } \\
\text { stimulation every } \\
6 \text { months might } \\
\text { be sufficient to } \\
\text { produce a } \\
\text { sustained clinical } \\
\text { effect. }\end{array}$ \\
\hline $\begin{array}{l}\text { Zhao et al., } \\
2017\end{array}$ & $\begin{array}{l}30 \text { mild to } \\
\text { moderate } A D \\
\text { patients }\end{array}$ & $\begin{array}{l}\text { Exclusion of patients } \\
\text { with a history of } \\
\text { alcohol abuse or } \\
\text { who had taken } \\
\text { psychoactive } \\
\text { medications within } \\
\text { the past month }\end{array}$ & $\begin{array}{l}\text { Sham and } \\
\text { stimulation } \\
\text { groups. } 20 \mathrm{~Hz}, 20 \\
\mathrm{~s} \text { intermediate/ } \\
\text { train. } 1 \text { session/ } \\
\text { day, } 5 \mathrm{~d} / \text { week for } \\
6 \text { weeks }\end{array}$ & $\begin{array}{l}\text { Parietal P3/P4 } \\
\text { and posterior } \\
\text { temporal T5/T6 } \\
\text { according to } \\
\text { electroence- } \\
\text { phalogram } \\
\text { system }\end{array}$ & $\begin{array}{l}\text { ADAS-cog, } \\
\text { MMSE, } \\
\text { MoCA, WHO- } \\
\text { UCLA AVLT }\end{array}$ & $\begin{array}{l}\text { Baseline, end of } \\
\text { treatment and } 6 \\
\text { weeks after the end } \\
\text { of treatment }\end{array}$ & $\begin{array}{l}\text { Patients improved on } \\
\text { ADAS-cog, MMSE, } \\
\text { MoCA and WHO- } \\
\text { UCLA AVLT after the } \\
\text { treatment. } 6 \text { weeks } \\
\text { following treatment, } \\
\text { patients further } \\
\text { improved on ADAS- } \\
\text { cog and WHO-UCLA } \\
\text { AVLT remained higher. } \\
\text { The sham group also } \\
\text { improved on ADAS- } \\
\text { cog compared to } \\
\text { pretreatment. }\end{array}$ & $\begin{array}{l}\text { rTMS improves } \\
\text { cognitive level, } \\
\text { memory and } \\
\text { language of } A D \\
\text { patients, } \\
\text { especially in the } \\
\text { mild stage. Thus, } \\
\text { rTMS can be } \\
\text { recommended as } \\
\text { a promising } \\
\text { adjuvant therapy } \\
\text { combined with } \\
\text { cholinesterase } \\
\text { inhibitors at the } \\
\text { mild stage of AD } \\
\text { patients. }\end{array}$ \\
\hline $\begin{array}{l}\text { Koch et al., } \\
2018\end{array}$ & 14 mild $A D$ & $\begin{array}{l}\text { AD confirmed by } \\
\text { CSF protein levels }\end{array}$ & $\begin{array}{l}\text { Sham and } \\
\text { stimulation groups } \\
\text { (crossover } \\
\text { design). Two } \\
\text { weeks of } 20 \mathrm{~Hz} \\
\text { stimulation ( } 40 \\
\text { trains, for } 2 \mathrm{~s}, \\
1600 \text { pulses/d) }\end{array}$ & Precuneus & $\begin{array}{l}\text { RAVLT, DSST, } \\
\text { MMSE and } \\
\text { FAB }\end{array}$ & $\begin{array}{l}\text { Baseline and end of } \\
\text { treatment }\end{array}$ & $\begin{array}{l}\text { Patients improved on } \\
\text { the Delayed Recall of } \\
\text { RAVLT at the end of } \\
\text { treatment. No } \\
\text { significant effects after } \\
\text { sham stimulation. }\end{array}$ & $\begin{array}{l}\text { High-frequency } \\
\text { rTMS is a } \\
\text { promising } \\
\text { treatment for } \\
\text { memory } \\
\text { impairment in } \\
\text { patients at early } \\
\text { stages of AD. }\end{array}$ \\
\hline
\end{tabular}

ADAS-ADL, Alzheimer Disease Assessment Scale-Activities of Daily Living subscale; B-ADL, Bayer Activities of Daily Living Scale; DSST, Digit Symbol Substitution Test; FAB, Frontal Assessment Battery; HAMILTON, Hamilton Depression Scale; IQCODE, Informant Questionnaire on Cognitive Decline in the Elderly; MoCA, Montreal Cognitive Assessment; NPI, Neuropsychiatric Inventory; pSAC, parietal somatosensory association cortex; RAVLT, Rey Auditory Verbal Learning Test; RMBC, Revised Memory and Behavior Checklist; RBMT, Rivermead Behavioral Memory Test; SC-BADA, Battery for Analysis of Aphasic Deficits; TMT A/B, Trail Making test A and B; WHO-UCLA AVLT, World Health Organization University of California-Los Angeles, Auditory Verbal Learning Test.

Instrumental Activities of Daily Living Scale (IADL), and the Global Deterioration Scale (GDS)], and the benefits persisted at all test intervals (i.e., up to 3 months). In contrast, participants with severe dementia showed no improvement, regardless of stimulation protocol. A second study also examined the effects of dIPFC stimulation, but in this case, while healthy control subjects received either uni- lateral iTBS or $1 \mathrm{~Hz}$ rTMS, participants with $\mathrm{MCl}$ received only unilateral $1 \mathrm{~Hz}$ stimulation (Turriziani et al., 2012). Recognition memory improved in both cognitively healthy and $\mathrm{MCl}$ subjects following low-frequency stimulation of the right dIPFC compared with sham. Intriguingly, highfrequency TMS over the same site in control subjects impaired recognition memory, raising the possibility that 
the cognitive response to TMS is dependent on stimulation frequency and/or the baseline status of memory. Unfortunately, the effects of iTBS in memory-impaired participants, with $\mathrm{MCl}$, were not reported (Turriziani et al., 2012).

Encouraged by this background, together with the much larger literature of experimental studies in normal participants (Iriarte and George, 2018), stimulation protocols specifically intended for clinical application in individuals with mild to moderate $A D$ are under active development. Using high-frequency rTMS in conjunction with concurrent cognitive training (rTMS-COG), one current strategy involves an intensive phase of $10 \mathrm{~Hz}$ stimulation at six different cortical sites (bilateral dIPFC, parietal somatosensory association cortices, and Broca's and Wernicke's areas), nominally three regions/d, $5 \mathrm{~d} /$ week for 6 weeks. Alongside rTMS, in this regimen patients receive cognitive training overlapping with TMS delivery, specifically tailored to engage the brain regions targeted for electromagnetic stimulation. A maintenance phase has been included in some studies, composed of two subsequent sessions/week for 3 months. In the first study examining the effects of rTMS-COG (Bentwich et al., 2011), improvement in the AD Assessment Scale-cognitive subscale (ADAS-Cog) was observed at 6 weeks and 4.5 months relative to pretreatment scores. Similar findings in other studies include improved ADAS-Cog and MMSE scores 6 weeks post-treatment (Rabey and Dobronevsky, 2016), and increased ADAS-Cog and Clinical Global Impression of Change (CGIC) scores at 6 weeks, 3 months, and 4.5 months (Rabey et al., 2013) compared with placebo stimulation.

Complementing these findings, rTMS-COG in a group of probable $A D$ case patients reportedly produced statistically significant or numerical improvement relative to baseline, as assessed by a variety of standard measures (e.g., CGIC, MMSE, or ADAS-Cog), either immediately or 6 weeks after the intervention protocol (Lee et al., 2016). Effects were most robust among participants with mild $A D$ and were not detected in those with more advanced cognitive deficits. Notably, however, scores also improved in a parallel sham condition, and, accordingly, interactions between treatment condition and assessment episode were not statistically significant. The endurance of potential treatment benefit in $A D$ remains to be fully documented, but in a recent study (Nguyen et al., 2017) improved ADAS-Cog scores seen $45 \mathrm{~d}$ after rTMSCOG reverted to pretreatment baseline at 6 months after intervention. The lack of a sham control that might have detected worse decline without treatment complicates the interpretation of this work (Nguyen et al., 2017).

\section{Toward an approved TMS therapy for AD}

Important issues remain to be addressed in the potential clinical application of rTMS in AD. A recent FDA review for approval of a commercial TMS system for treatment of $A D$ identified a number of deficiencies that need to be addressed, including uncertainty around the reporting of adverse events, concern that current evidence fails to demonstrate a clinically meaningful TMS benefit in $A D$, and agreement that there are insufficient data documenting that the benefits of the proposed therapy outweigh its health risks (see www.fda.gov, March 21, 2019, Neurological Devices Panel of the Medical Devices Advisory Committee: De Novo DEN160053). The following sections briefly consider some of the experimental design challenges in this area of research, and then turn to evidence concerning the neurobiological mechanisms that might mediate the effects of TMS. A comprehensive mechanistic review is available elsewhere (Keck, 2003; Pell et al., 2011). The perspective here is more targeted, suggesting, on the basis of converging evidence, that NIBS protocols with established safety in healthy young adults may have different effects in the context of $A D$ pathogenesis. Finally, we outline key issues that will need to be resolved in order to advance the rational application of rTMS and related technologies for the prevention, symptomatic relief, or disease-modifying treatment of AD.

\section{Challenges in assessing rTMS effects in AD}

As noted earlier, TMS is approved for the treatment of medication-resistant depression (McClintock et al., 2018; Kaster et al., 2019). Accordingly, in AD trials it is important to control for the possibility that patients might benefit from TMS secondary to stimulation effects on comorbid depressive symptoms (Cotelli et al., 2006, 2008). The prevalence of depression in $A D$ may be as high as $50 \%$ (Rutherford et al., 2013), and even mild depressive symptoms are associated with significant functional impairment (Starkstein et al., 2005). Many of the stimulation protocols tested for the treatment of $A D$ are similar to those used in depression, including a prominent focus on the dIPFC. Although some studies have explicitly excluded patients with depression (Cotelli et al., 2006, 2008, 2011; Turriziani et al., 2012; Drumond Marra et al., 2015), others have not reported mood disorders as an exclusion criterion (Ahmed et al., 2012; Rabey et al., 2013; Eliasova et al., 2014; Rabey and Dobronevsky, 2016; Nguyen et al., 2017). The degree to which cognitive improvement following TMS in AD results from alleviating depressive symptoms is therefore difficult to judge, but it is notable in this context that treated patients sometimes also exhibit elevated mood, scoring better on depression and apathy scales (Ahmed et al., 2012; Lee et al., 2016; Nguyen et al., 2017; Padala et al., 2018).

Other experimental controls have also been lacking at times in this area of work. In a number of reports, potential improvements in performance simply as a consequence of repeating cognitive assessment across multiple occasions (i.e., practice effects) were not considered. Studies examining rTMS-COG protocols have generally lacked groups receiving either rTMS alone or cognitive assessment without stimulation (recent preliminary findings are an exception (Alcalá-Lozano et al., 2018), and in such cases the individual and interactive contributions of training and TMS are unknown. Whether they are independent, competitive, or synergistic, there is considerable precedent for the idea that the effects of rTMS are "state dependent" and critically modulated by concurrent func- 
tional engagement of the neural circuitry targeted by stimulation (Silvanto et al., 2008). The precise schedule of cognitive training relative to epochs of rTMS delivery, however, has not been systematically manipulated in $A D$ trials. Small sample size is another limitation, and in many investigations, groups of a dozen or fewer participants are not uncommon. Much larger samples, offering increased statistical power, are needed to accurately estimate effect size and enhance reproducibility (Button et al., 2013). As noted in the FDA review cited earlier and in previous reports (Buss et al., 2019; Koch et al., 2019), properly designed, larger, and longer trials are needed to address unresolved issues in the use of rTMS as a therapeutic treatment for AD.

Studies reporting positive TMS effects in mild $A D$ have failed to find reliable benefit in more advanced cases (Ahmed et al., 2012; Rutherford et al., 2015; Lee et al., 2016; Zhao et al., 2017), suggesting that treatment efficacy may be dependent on disease stage. As proposed for other interventions, rTMS might be most effective early in the course of the disease, before neuronal loss has disrupted critical cortical circuitry beyond rescue. The accuracy of early disease diagnosis and staging is an endemic challenge in clinical research on $A D$, and estimates are that nearly $20 \%$ of cases are misdiagnosed (Witte et al., 2014). Thus, important goals for future clinical trials of rTMS include an increased focus on participants qualified on the basis of neuroimaging or biomarker results, and cognitively normal samples at increased risk for the development of disease (e.g., on the basis of APOE genotype or polygenic risk). To date, no longitudinal clinical trial has investigated the response to rTMS-COG in individuals with prodromal or asymptomatic $A D$, when arresting or reversing neuronal dysfunction may have the greatest prospects of success.

\section{Potential mechanisms of rTMS benefits}

The rTMS protocols tested most frequently as potential interventions for $A D$ were selected partly on the basis of the persistent enhancement in cortical excitability observed following repetitive high-frequency stimulation (Huang et al., 2005; Pötter-Nerger et al., 2009). Such facilitation is thought to involve long-term potentiation (LTP)-like changes in synaptic strength that are widely presumed to be a key cellular mechanism of learning and memory. LTP induced by high-frequency magnetic stimulation $(100 \mathrm{~Hz})$ has been directly documented in rat hippocampal slices (Tokay et al., 2009), and related synaptic enhancement has been reported in both other slice preparations and primary cortical cell cultures following 10 and $20 \mathrm{~Hz}$ magnetic stimulation (Vlachos et al., 2012; Banerjee et al., 2017). Neuronal activity and LTP regulate the expression of plasticity-related neurotrophins such as brain-derived neurotrophic factor (BDNF), which declines in the AD hippocampus (Phillips et al., 1991), and animal studies confirm that high-frequency rTMS can significantly upregulate BDNF levels (Makowiecki et al., 2014). The speculation based on these findings is that rTMS might result in clinical benefit by correcting or blunting the impaired LTP-like plasticity and associated signaling defects observed in AD (Kumar et al., 2017).

In parallel with these findings, recent advances have also identified rTMS as a modifier of inhibitory neuron function. Studies in hippocampal slice cultures demonstrate that $10 \mathrm{~Hz}$ stimulation reduces GABAergic synaptic strength on principal neurons, supporting a model in which mechanisms involving GABAergic synapses modulate overall inhibitory/excitatory balance (Lenz et al., 2016). Findings based on immunocytochemical analysis in animals (Trippe et al., 2009; Mix et al., 2010; Benali et al., 2011) and magnetic resonance spectroscopy in humans (Stagg et al., 2009) show that TMS can lead to temporally graded changes in a variety of inhibitory neuronal markers, lasting at least a week. In preclinical animal research, such alterations generally comprise increases in GABAergic synthesizing enzymes and transporters after low-frequency stimulation (Trippe et al., 2009; Mix et al., 2010 ; i.e., changes that might promote a net increase in inhibitory drive) and decreases in the number of immunocytochemically identified inhibitory cells after highfrequency stimulation (Benali et al., 2011; Jazmati et al., 2018).

Other mechanisms implicated in the pathogenesis of AD that might contribute to the cognitive effects of rTMS in $A D$ include neurochemical modulation (Michael et al., 2003; Strafella et al., 2003), epigenetic modification of gene transcription (Etiévant et al., 2015), and modulatory effects on neural network dynamics in vulnerable circuitry (Marron et al., 2018). The effect of TMS on these and other potential mechanisms, however, has received limited attention. In the following section, we focus on a particularly illuminating example, suggesting a potential link between the modulatory influence of rTMS on excitatory/inhibitory balance with mechanisms of $A D$ pathogenesis.

\section{Excitatory/inhibitory balance in AD: a challenging opportunity}

Growing interest centers on the possibility that increases in neuronal activity levels directly contribute to $A D$ pathogenesis (Palop et al., 2006). Overexpression of $\mathrm{A} \beta$ causes epileptiform activity within entorhinal-hippocampal circuitry that, together with homeostatic responses to aberrant firing, may contribute to memory dysfunction in transgenic mouse models and humans with $A D$ (Palop et al., 2007). Soluble oligomeric $A \beta$ assemblies also increase neuronal excitability and impair hippocampal function by inducing an imbalance between glutamatergic and GABAergic transmission (Lei et al., 2016). The strongest known genetic risk for sporadic $A D$, the APOE $\varepsilon 4$ allele, disrupts GABAergic inhibitory networks, influencing both $A \beta$ aggregation and the clearance of soluble $A \beta$. In AD mouse models, APOE $\varepsilon 4$ knock-in leads to a decrease in GABAergic interneurons in the hilar region of the dentate gyrus that correlates with learning and memory impairment (Li et al., 2009; Huang and Mucke, 2012). This effect, in turn, is reversible with hilar transplantation of inhibitory interneurons (Tong et al., 2014). Relative to noncarriers, the $\varepsilon 4$-positive genotype in young adult humans is associated with both hippocampal hyperactivity 


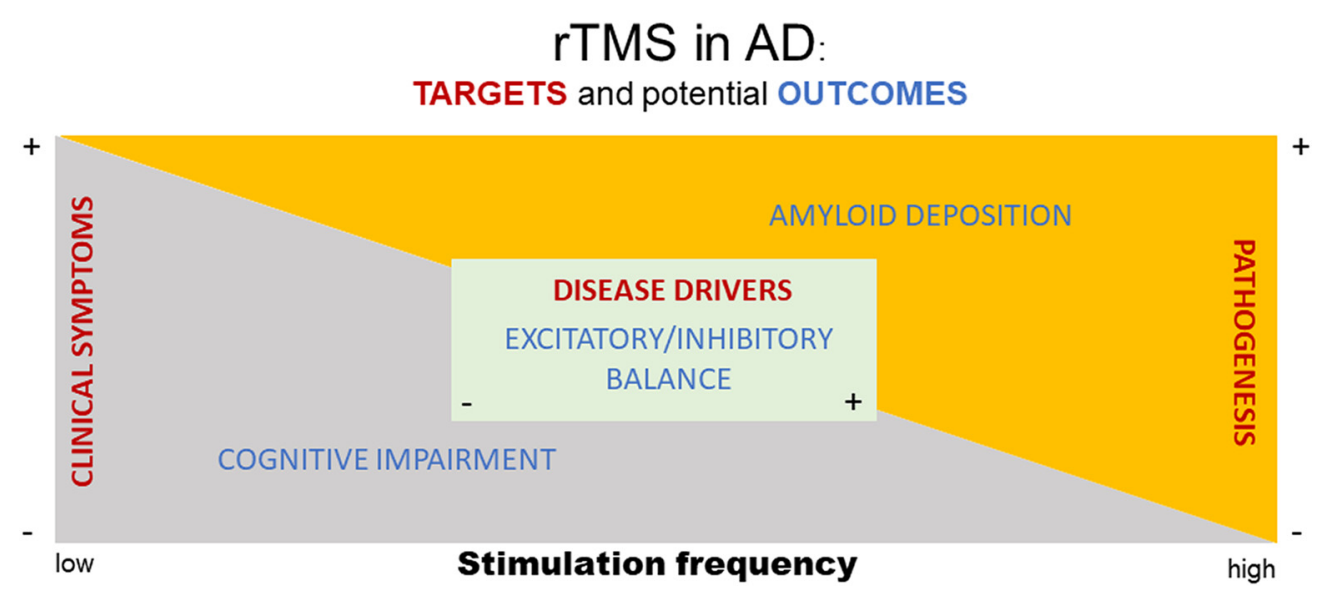

Figure 1. Schematic representation of target areas (red text) and potential outcome measures (blue text) to test rTMS as an intervention for AD. See text for further description.

during memory encoding and increased resting-state connectivity, many decades before clinical or neurophysiological expression of neurodegenerative processes (Filippini et al., 2009). Basic research points to a potential feedforward effect, demonstrating that neuronal stimulation in hippocampal slice preparations induces amyloid precursor protein release (Nitsch et al., 1993), and that stimulating entorhinal cortex projections to the hippocampus increases interstitial $A \beta$ in AD mice (Kamenetz et al., 2003). Thus, together the available findings strongly suggest that neuronal activity is linked to $A \beta$ processing and release, specifically in circuitry known to be affected early in the course of AD (Jagust and Mormino, 2011).

Prompted by the failure of recent clinical trials aimed at slowing or stopping the progression of $A D$, attention has turned to novel approaches targeting earlier, preclinical abnormalities. Whereas the direction of effect between disrupted neural network activity and AD pathogenesis may vary across brain regions and stages of disease, the emerging consensus is that distributed changes in neuronal excitability are an early signature conferring increased risk for AD (Palop and Mucke, 2010). In this context, therapies aimed at normalizing the balance between excitatory and inhibitory drive in vulnerable circuitry represent a potentially powerful approach to modifying the course of $A D$. Preliminary support includes evidence that GABA receptor agonist administration in AD transgenic mice (Shao et al., 2014) and aged mice (Yamamoto et al., 2015), as well as in humans (Chung et al., 2016), lowers $A \beta$ burden and attenuates $A \beta$-induced neurotoxicity. Other treatments, including the use of growth hormone-releasing hormone in healthy elderly and $\mathrm{MCl}$ subjects, increase cortical GABA levels in association with improved cognition (Friedman et al., 2013). In perhaps the most direct test of targeting excess neuronal activity, low-dose treatment with the antiepileptic levetiracetam improves memory in both aged rats (Koh et al., 2010) and individuals with amnestic $\mathrm{MCl}$ (Bakker et al., 2012), together with a reduction in hippocampal hyperactivity. Whether this approach, implemented early, is sufficient to alter the fundamental trajectory of disease is under active investigation.

\section{Frontiers in AD management and treatment using TMS: a path forward}

The possibility that a safe, noninvasive, and relatively lowcost treatment such as TMS might prove effective in the battle against $A D$ has generated understandable excitement (https:// www.scientificamerican.com/article/could-magnetic-brainstimulation-help-people-with-alzheimer-rsquo-s/). However, the available evidence regarding clinical efficacy and mechanism of action is limited. The view developed here is that defining the neurobiological substrates responsible for the effects of TMS and other NIBS modalities will be critical for maximizing their efficacy and safety. We encourage a constructive, dispassionate evaluation of the evidence, aimed at establishing an informed platform for moving TMS and related strategies forward toward clinical application in AD.

The evidence summarized in this review highlights at least three conceptually distinct targets for TMS intervention in AD. Figure 1 schematically represents the hypothetical relationships between these targets (red text), together with an exemplar outcome for each (blue text), and how they might vary with low- versus high-frequency TMS. The majority of extant research in this area has examined stimulation effects on cognitive and neuropsychological symptoms of disease, with the primary outcome of interest comprising improved clinical outcome. The effects of high-frequency stimulation have been tested most often, with positive studies reporting a variable degree of cognitive benefit, at least in mild AD. Insufficient attention has been directed at tracking the influence of TMS on AD pathogenesis or biomarkers (i.e., proxies of the underlying disease process; for example, see Marron et al., 2018). Nonetheless, substantial evidence indicates that neuronal activity promotes amyloid deposition, raising the possibility that the same highfrequency stimulation that leads to improved clinical symptoms might also accelerate underlying AD pathogenesis. Conversely, low-frequency rTMS reportedly decreases amyloid burden in the brains of $A D$ transgenic mice (Huang et al., 2017), while preserving the reported cognitive benefit of high-frequency stimulation. Finally, perhaps the most hopeful target of TMS in AD-that 
intervening before symptom onset might correct contributing mechanisms or block seed events in the initiation of the disease process-remains largely untested. Disrupted excitatory/inhibitory balance is thought to comprise an early driver of $A D$ pathogenesis, and, based on its presumed mechanism of action, TMS may be ideally positioned as a disease-modifying intervention against this target.

The need for effective strategies in the battle against $A D$ grows ever more urgent. The disappointing outcome of recent clinical trials encourages the consideration of fresh perspectives, and in this context, NIBS has emerged as a novel alternative to pharmacological therapeutics and other interventions. The exciting potential of this approach, however, should not overshadow the important questions that remain unanswered. Among them, the safety profile established for other indications merits reconsideration in the context of neurobiological changes associated with $A D$, including hyperexcitability and epileptic activity, consistent with current safety guidelines (Rossi et al., 2009). Studies aimed at directly tracking pathological progression by in vivo imaging in patients receiving TMS are also needed. Efficacy in appropriately controlled, well powered trials remains to be confirmed, and longer-term cognitive outcomes established. At what stage in the progression of $A D$ pathology will TMS be most effective? If TMS is used to target excitatory/inhibitory balance, at what frequency and in which brain regions, recognizing that such effects may be brain region specific (Bañuelos et al., 2014)? Indeed, given the prominent regional vulnerability of $A D$, it will be important to consider that TMS aimed at correcting excitatory/inhibitory balance in one target area may well have unanticipated or negative secondary effects in other, distally connected networks. Basic research, designed in alignment with the priorities of clinical research, can provide helpful guidance and yield much needed insight into the neurobiological mechanisms responsible for the clinical effects of NIBS (Tang et al., 2017). The challenges are great, but a path forward toward the rational application of rTMS and related modalities in $A D$ has begun to emerge.

\section{References}

Ahmed MA, Darwish ES, Khedr EM, El Serogy YM, Ali AM (2012) Effects of low versus high frequencies of repetitive transcranial magnetic stimulation on cognitive function and cortical excitability in Alzheimer's dementia. J Neurol 259:83-92.

Alcalá-Lozano R, Morelos-Santana E, Cortés-Sotres JF, GarzaVillarreal EA, Sosa-Ortiz AL, González-Olvera JJ (2018) Similar clinical improvement and maintenance after rTMS at $5 \mathrm{~Hz}$ using a simple vs. complex protocol in Alzheimer's disease. Brain Stimul 11:625-627.

Bakker A, Krauss GL, Albert MS, Speck CL, Jones LR, Stark CE, Yassa MA, Bassett SS, Shelton AL, Gallagher M (2012) Reduction of hippocampal hyperactivity improves cognition in amnestic mild cognitive impairment. Neuron 74:467-474.

Banerjee J, Sorrell ME, Celnik PA, Pelled G (2017) Immediate effects of repetitive magnetic stimulation on single cortical pyramidal neurons. PLoS One 12:e0170528.

Bañuelos C, Beas BS, McQuail JA, Gilbert RJ, Frazier CJ, Setlow B, Bizon JL (2014) Prefrontal cortical GABAergic dysfunction contrib- utes to age-related working memory impairment. J Neurosci 34: 3457-3466.

Benali A, Trippe J, Weiler E, Mix A, Petrasch-Parwez E, Girzalsky W, Eysel UT, Erdmann R, Funke K (2011) Theta-burst transcranial magnetic stimulation alters cortical inhibition. J Neurosci 31:11931203.

Bentwich J, Dobronevsky E, Aichenbaum S, Shorer R, Peretz R, Khaigrekht M, Marton RG, Rabey JM (2011) Beneficial effect of repetitive transcranial magnetic stimulation combined with cognitive training for the treatment of Alzheimer's disease: a proof of concept study. J Neural Transm (Vienna) 118:463-471.

Buss SS, Fried PJ, Pascual-Leone A (2019) Therapeutic noninvasive brain stimulation in Alzheimer's disease and related dementias. Curr Opin Neurol 32:292-304.

Button KS, loannidis JP, Mokrysz C, Nosek BA, Flint J, Robinson ES, Munafò MR (2013) Power failure: why small sample size undermines the reliability of neuroscience. Nat Rev Neurosci 14:365376.

Chung JK, Nakajima S, Shinagawa S, Plitman E, Chakravarty MM, Iwata Y, Caravaggio F, Pollock BG, Gerretsen P, Graff-Guerrero A (2016) Benzodiazepine use attenuates cortical beta-amyloid and is not associated with progressive cognitive decline in nondemented elderly adults: a pilot study using F18-florbetapir positron emission tomography. Am J Geriatr Psychiatry 24:1028-1039.

Cotelli M, Manenti R, Cappa SF, Geroldi C, Zanetti O, Rossini PM, Miniussi C (2006) Effect of transcranial magnetic stimulation on action naming in patients with Alzheimer disease. Arch Neurol 63:1602-1604.

Cotelli M, Manenti R, Cappa SF, Zanetti O, Miniussi C (2008) Transcranial magnetic stimulation improves naming in Alzheimer disease patients at different stages of cognitive decline. Eur J Neurol 15:1286-1292.

Cotelli M, Calabria M, Manenti R, Rosini S, Zanetti O, Cappa SF, Miniussi C (2011) Improved language performance in Alzheimer disease following brain stimulation. J Neurol Neurosurg Psychiatry 82:794-797.

Drumond Marra HL, Myczkowski ML, Maia Memória C, Arnaut D, Leite Ribeiro P, Sardinha Mansur CG, Lancelote Alberto R, Boura Bellini B, Alves Fernandes da Silva A, Tortella G, Ciampi de Andrade D, Teixeira MJ, Forlenza OV, Marcolin MA (2015) Transcranial magnetic stimulation to address mild cognitive impairment in the elderly: a randomized controlled study. Behav Neurol 2015: 287843.

Eliasova I, Anderkova L, Marecek R, Rektorova I (2014) Non-invasive brain stimulation of the right inferior frontal gyrus may improve attention in early Alzheimer's disease: a pilot study. J Neurol Sci 346:318-322.

Etiévant A, Manta S, Latapy C, Magno LA, Fecteau S, Beaulieu JM (2015) Repetitive transcranial magnetic stimulation induces longlasting changes in protein expression and histone acetylation. Sci Rep 5:16873.

Farrer LA, Cupples LA, Haines JL, Hyman B, Kukull WA, Mayeux R, Myers RH, Pericak-Vance MA, Risch N, van Duijn CM (1997) Effects of age, sex, and ethnicity on the association between apolipoprotein E genotype and Alzheimer disease. A metaanalysis. APOE and Alzheimer Disease Meta Analysis Consortium. JAMA 278:1349-1356.

Filippini N, Maclntosh BJ, Hough MG, Goodwin GM, Frisoni GB, Smith SM, Matthews PM, Beckmann CF, Mackay CE (2009) Distinct patterns of brain activity in young carriers of the APOEepsilon4 allele. Proc Natl Acad Sci U S A 106:7209-7214.

Friedman SD, Baker LD, Borson S, Jensen JE, Barsness SM, Craft S, Merriam GR, Otto RK, Novotny EJ, Vitiello MV (2013) Growth hormone-releasing hormone effects on brain $\gamma$-aminobutyric acid levels in mild cognitive impairment and healthy aging. JAMA Neurol 70:883-890.

Guo Q, Li C, Wang J (2017) Updated review on the clinical use of repetitive transcranial magnetic stimulation in psychiatric disorders. Neurosci Bull 33:747-756. 
Health Quality Ontario (2016) Repetitive transcranial magnetic stimulation for treatment-resistant depression: a systematic review and meta-analysis of randomized controlled trials. Ont Health Technol Assess Ser 16:1-66.

Heffernan AL, Chidgey C, Peng P, Masters CL, Roberts BR (2016) The neurobiology and age-related prevalence of the $\varepsilon 4$ allele of apolipoprotein E in Alzheimer's disease cohorts. J Mol Neurosci 60:316-324.

Huang Y, Mucke L (2012) Alzheimer mechanisms and therapeutic strategies. Cell 148:1204-1222.

Huang YZ, Edwards MJ, Rounis E, Bhatia KP, Rothwell JC (2005) Theta burst stimulation of the human motor cortex. Neuron 45: 201-206.

Huang Z, Tan T, Du Y, Chen L, Fu M, Yu Y, Zhang L, Song W, Dong $Z$ (2017) Low-frequency repetitive transcranial magnetic stimulation ameliorates cognitive function and synaptic plasticity in APP23/PS45 mouse model of Alzheimer's disease. Front Aging Neurosci 9:292.

Iriarte IG, George MS (2018) Transcranial magnetic stimulation (TMS) in the elderly. Curr Psychiatry Rep 20:6.

Jagust WJ, Mormino EC (2011) Lifespan brain activity, $\beta$-amyloid, and Alzheimer's disease. Trends Cogn Sci 15:520-526.

Jazmati D, Neubacher U, Funke K (2018) Neuropeptide Y as a possible homeostatic element for changes in cortical excitability induced by repetitive transcranial magnetic stimulation. Brain Stimul 11:797-805.

Kamenetz F, Tomita T, Hsieh H, Seabrook G, Borchelt D, Iwatsubo T, Sisodia S, Malinow R (2003) APP processing and synaptic function. Neuron 37:925-937.

Kar SK (2019) Predictors of response to repetitive transcranial magnetic stimulation in depression: a review of recent updates. Clin Psychopharmacol Neurosci 17:25-33.

Kaster TS, Fitzgerald PB, Downar J, Vila-Rodriguez F, Daskalakis ZJ, Blumberger DM (2019) Considerable evidence supports rTMS for treatment-resistant depression. J Affect Disord. Advance online publication. Retrieved December 16, 2019. doi:10.1016/ j.jad.2019.11.017.

Keck ME (2003) rTMS as treatment strategy in psychiatric disordersneurobiological concepts. Suppl Clin Neurophysiol 56:100-116.

Koch G, Bonni S, Pellicciari MC, Casula EP, Mancini M, Esposito R, Ponzo V, Picazio S, Di Lorenzo F, Serra L, Motta C, Maiella M, Marra C, Cercignani M, Martorana A, Caltagirone C, Bozzali M (2018) Transcranial magnetic stimulation of the precuneus enhances memory and neural activity in prodromal Alzheimer's disease. Neuroimage 169:302-311.

Koch G, Martorana A, Caltagirone C (2019) Transcranial magnetic stimulation: emerging biomarkers and novel therapeutics in Alzheimer's disease. Neurosci Lett. Advance online publication. Retrieved December 16, 2019. doi:10.1016/j.neulet.2019.134355.

Koh MT, Haberman RP, Foti S, McCown TJ, Gallagher M (2010) Treatment strategies targeting excess hippocampal activity benefit aged rats with cognitive impairment. Neuropsychopharmacology 35:1016-1025.

Kumar S, Zomorrodi R, Ghazala Z, Goodman MS, Blumberger DM, Cheam A, Fischer C, Daskalakis ZJ, Mulsant BH, Pollock BG, Rajji TK (2017) Extent of dorsolateral prefrontal cortex plasticity and its association with working memory in patients with Alzheimer disease. JAMA Psychiatry 74:1266-1274.

Lang N, Harms J, Weyh T, Lemon RN, Paulus W, Rothwell JC, Siebner HR (2006) Stimulus intensity and coil characteristics influence the efficacy of rTMS to suppress cortical excitability. Clin Neurophysiol 117:2292-2301.

Lee J, Choi BH, Oh E, Sohn EH, Lee AY (2016) Treatment of Alzheimer's disease with repetitive transcranial magnetic stimulation combined with cognitive training: a prospective, randomized, double-blind, placebo-controlled study. J Clin Neurol 12:57-64.

Lei M, Xu H, Li Z, Wang Z, O'Malley TT, Zhang D, Walsh DM, Xu P, Selkoe DJ, Li S (2016) Soluble A $\beta$ oligomers impair hippocampal LTP by disrupting glutamatergic/GABAergic balance. Neurobiol Dis $85: 111-121$.
Lenz M, Galanis C, Müller-Dahlhaus F, Opitz A, Wierenga CJ, Szabó G, Ziemann U, Deller T, Funke K, Vlachos A (2016) Repetitive magnetic stimulation induces plasticity of inhibitory synapses. Nat Commun 7:10020.

Li G, Bien-Ly N, Andrews-Zwilling Y, Xu Q, Bernardo A, Ring K, Halabisky B, Deng C, Mahley RW, Huang Y (2009) GABAergic interneuron dysfunction impairs hippocampal neurogenesis in adult apolipoprotein E4 knockin mice. Cell Stem Cell 5:634-645.

Makowiecki K, Harvey AR, Sherrard RM, Rodger J (2014) Lowintensity repetitive transcranial magnetic stimulation improves abnormal visual cortical circuit topography and upregulates BDNF in mice. J Neurosci 34:10780-10792.

Marron EM, Viejo-Sobera R, Quintana M, Redolar-Ripoll D, Rodríguez D, Garolera M (2018) Transcranial magnetic stimulation intervention in Alzheimer's disease: a research proposal for a randomized controlled trial. BMC Res Notes 11:648.

McClintock SM, Reti IM, Carpenter LL, McDonald WM, Dubin M, Taylor SF, Cook IA, O'Reardon J, Husain MM, Wall C, Krystal AD, Sampson SM, Morales O, Nelson BG, Latoussakis V, George MS, Lisanby SH (2018) Consensus recommendations for the clinical application of repetitive transcranial magnetic stimulation (rTMS) in the treatment of depression. J Clin Psychiatry 79:16cs10905.

Michael N, Gösling M, Reutemann M, Kersting A, Heindel W, Arolt V, Pfleiderer B (2003) Metabolic changes after repetitive transcranial magnetic stimulation (rTMS) of the left prefrontal cortex: a shamcontrolled proton magnetic resonance spectroscopy (1H MRS) study of healthy brain. Eur J Neurosci 17:2462-2468.

Mix A, Benali A, Eysel UT, Funke K (2010) Continuous and intermittent transcranial magnetic theta burst stimulation modify tactile learning performance and cortical protein expression in the rat differently. Eur J Neurosci 32:1575-1586.

Nguyen JP, Suarez A, Kemoun G, Meignier M, Le Saout E, Damier P, Nizard J, Lefaucheur JP (2017) Repetitive transcranial magnetic stimulation combined with cognitive training for the treatment of Alzheimer's disease. Neurophysiol Clin 47:47-53.

Nitsch RM, Farber SA, Growdon JH, Wurtman RJ (1993) Release of amyloid beta-protein precursor derivatives by electrical depolarization of rat hippocampal slices. Proc Natl Acad Sci U S A 90:5191-5193.

Padala PR, Padala KP, Lensing SY, Jackson AN, Hunter CR, Parkes CM, Dennis RA, Bopp MM, Caceda R, Mennemeier MS, Roberson PK, Sullivan DH (2018) Repetitive transcranial magnetic stimulation for apathy in mild cognitive impairment: a double-blind, randomized, sham-controlled, cross-over pilot study. Psychiatry Res 261:312-318.

Palop JJ, Mucke L (2010) Amyloid-beta-induced neuronal dysfunction in Alzheimer's disease: from synapses toward neural networks. Nat Neurosci 13:812-818.

Palop JJ, Chin J, Mucke L (2006) A network dysfunction perspective on neurodegenerative diseases. Nature 443:768-773.

Palop JJ, Chin J, Roberson ED, Wang J, Thwin MT, Bien-Ly N, Yoo J, Ho KO, Yu GQ, Kreitzer A, Finkbeiner S, Noebels JL, Mucke L (2007) Aberrant excitatory neuronal activity and compensatory remodeling of inhibitory hippocampal circuits in mouse models of Alzheimer's disease. Neuron 55:697-711.

Pell GS, Roth Y, Zangen A (2011) Modulation of cortical excitability induced by repetitive transcranial magnetic stimulation: influence of timing and geometrical parameters and underlying mechanisms. Prog Neurobiol 93:59-98.

Phillips HS, Hains JM, Armanini M, Laramee GR, Johnson SA, Winslow JW (1991) BDNF mRNA is decreased in the hippocampus of individuals with Alzheimer's disease. Neuron 7:695-702.

Pohar R, Farrah K (2019) CADTH rapid response reports. In: Repetitive transcranial magnetic stimulation for patients with depression: a review of clinical effectiveness, cost-effectiveness and guidelines-an update. Ottawa: Canadian Agency for Drugs and Technologies in Health.

Pötter-Nerger M, Fischer S, Mastroeni C, Groppa S, Deuschl G, Volkmann J, Quartarone A, Münchau A, Siebner HR (2009) Induc- 
ing homeostatic-like plasticity in human motor cortex through converging corticocortical inputs. J Neurophysiol 102:3180-3190.

Rabey JM, Dobronevsky E (2016) Repetitive transcranial magnetic stimulation (rTMS) combined with cognitive training is a safe and effective modality for the treatment of Alzheimer's disease: clinical experience. J Neural Transm (Vienna) 123:1449-1455.

Rabey JM, Dobronevsky E, Aichenbaum S, Gonen O, Marton RG, Khaigrekht M (2013) Repetitive transcranial magnetic stimulation combined with cognitive training is a safe and effective modality for the treatment of Alzheimer's disease: a randomized, doubleblind study. J Neural Transm (Vienna) 120:813-819.

Rossi S, Hallett M, Rossini PM, Pascual-Leone A (2009) Safety, ethical considerations, and application guidelines for the use of transcranial magnetic stimulation in clinical practice and research. Clin Neurophysiol 120:2008-2039.

Rutherford G, Gole R, Moussavi Z (2013) rTMS as a treatment of Alzheimer's disease with and without comorbidity of depression: a review. Neurosci J 2013:679389.

Rutherford G, Lithgow B, Moussavi Z (2015) Short and long-term effects of rTMS treatment on Alzheimer's disease at different stages: a pilot study. J Exp Neurosci 9:43-51.

Selkoe DJ (2001) Alzheimer's disease: genes, proteins, and therapy. Physiol Rev 81:741-766.

Shao H, Zhang Y, Dong Y, Yu B, Xia W, Xie Z (2014) Chronic treatment with anesthetic propofol improves cognitive function and attenuates caspase activation in both aged and Alzheimer's disease transgenic mice. J Alzheimers Dis 41:499-513.

Silvanto J, Muggleton N, Walsh V (2008) State-dependency in brain stimulation studies of perception and cognition. Trends Cogn Sci 12:447-454.

Stagg CJ, Wylezinska M, Matthews PM, Johansen-Berg H, Jezzard P, Rothwell JC, Bestmann S (2009) Neurochemical effects of theta burst stimulation as assessed by magnetic resonance spectroscopy. J Neurophysiol 101:2872-2877.

Starkstein SE, Jorge R, Mizrahi R, Robinson RG (2005) The construct of minor and major depression in Alzheimer's disease. Am J Psychiatry 162:2086-2093.

Strafella AP, Paus T, Fraraccio M, Dagher A (2003) Striatal dopamine release induced by repetitive transcranial magnetic stimulation of the human motor cortex. Brain 126:2609-2615.
Tang A, Thickbroom G, Rodger J (2017) Repetitive transcranial magnetic stimulation of the brain: mechanisms from animal and experimental models. Neuroscientist 23:82-94.

Tokay T, Holl N, Kirschstein T, Zschorlich V, Köhling R (2009) Highfrequency magnetic stimulation induces long-term potentiation in rat hippocampal slices. Neurosci Lett 461:150-154.

Tong LM, Djukic B, Arnold C, Gillespie AK, Yoon SY, Wang MM, Zhang O, Knoferle J, Rubenstein JL, Alvarez-Buylla A, Huang Y (2014) Inhibitory interneuron progenitor transplantation restores normal learning and memory in ApoE4 knock-in mice without or with $A \beta$ accumulation. J Neurosci 34:9506-9515.

Trippe J, Mix A, Aydin-Abidin S, Funke K, Benali A (2009) $\theta$ burst and conventional low-frequency rTMS differentially affect GABAergic neurotransmission in the rat cortex. Exp Brain Res 199:411-421.

Turriziani P, Smirni D, Zappalà G, Mangano GR, Oliveri M, Cipolotti $L$ (2012) Enhancing memory performance with rTMS in healthy subjects and individuals with mild cognitive impairment: the role of the right dorsolateral prefrontal cortex. Front Hum Neurosci 6:62.

Vlachos A, Müller-Dahlhaus F, Rosskopp J, Lenz M, Ziemann U, Deller T (2012) Repetitive magnetic stimulation induces functional and structural plasticity of excitatory postsynapses in mouse organotypic hippocampal slice cultures. J Neurosci 32:1751417523.

Wei Y, Zhu J, Pan S, Su H, Li H, Wang J (2017) Meta-analysis of the efficacy and safety of repetitive transcranial magnetic stimulation (rTMS) in the treatment of depression. Shanghai Arch Psychiatry 29:328-342.

Witte MM, Trzepacz P, Case M, Yu P, Hochstetler H, Quinlivan M, Sundell K, Henley D (2014) Association between clinical measures and florbetapir F18 PET neuroimaging in mild or moderate Alzheimer's disease dementia. J Neuropsychiatry Clin Neurosci 26:214220.

Yamamoto N, Arima H, Sugiura T, Hirate H, Kusama N, Suzuki K, Sobue K (2015) Midazolam inhibits the formation of amyloid fibrils and GM1 ganglioside-rich microdomains in presynaptic membranes through the gamma-aminobutyric acid A receptor. Biochem Biophys Res Commun 457:547-553.

Zhao J, Li Z, Cong Y, Zhang J, Tan M, Zhang H, Geng N, Li M, Yu W, Shan $P$ (2017) Repetitive transcranial magnetic stimulation improves cognitive function of Alzheimer's disease patients. Oncotarget 8:33864-33871. 